\title{
Comments on "Green IT: A Matter of Business and Information Systems Engineering?"
}

\section{DOI 10.1007/s12599-011-0190-4}

\section{The Author}

Prof. Dr. Andreas Gadatsch ( $\varangle)$

Professor of Business Information

Systems

Bonn-Rhein-Sieg University

of Applied Sciences

Grantham-Allee 20

53757 Sank Augustin

Germany

Andreas.Gadatsch@h-brs.de

Published online: 2011-10-28

This article is also available in German in print and via http://www. wirtschaftsinformatik.de: Loos, P, Gadatsch A (2011) Kommentar zu "Green IT: Ein Thema für die Wirtschaftsinformatik?". WIRTSCHAFTSINFORMATIK. doi: 10.1007/s11576-0110300-4.

(c) Gabler Verlag 2011

\section{Green IT and IT Controlling}

In issue 4/2011, Peter Loos and other authors gratefully discussed the question of "Green IT: A matter of Business and Information Systems Engineering?" (Loos et al. 2011). We have investigated this issue in recent years from an IT controlling perspective.
The increased costs for energy have led to a rethinking of IT management. Under the heading of "Green IT" many companies take measures to reduce their energy consumption and thus the cost of IT operations. In some cases, this even led to new occupational profiles, such as the "Chief Sustainability Officer" who is supposed to coordinate the activities within the company. According to a study of Deutsche Bank Research, 38\% of companies already have appointed a "Green IT officer” (Deutsche Bank Research 2011, p. 5).

In two surveys (2009 and 2011) among IT controllers and IT managers (CIO, etc.) we have analyzed the spread of Green IT initiatives and their achieved success as well as future plans of the companies (Gadatsch and Juszczak 2009, 2011). As part of our surveys, we found that about $60 \%$ of the companies initiated Green IT activities, usually on the part of the CIO but also partly by the company management. In addition, in the current survey mainly IT controllers in bigger companies are dealing with Green IT, mostly to realize cost savings. Although already great success was achieved particularly in the context of data center management (cooling, building services) and software management (cloud computing), there is still need for action since the companies are not always satisfied with the results obtained.

In our opinion there is still significant need for action in research regarding the issues of certification and maturity determination. Only 7\% of the companies surveyed stated, for example, to make use of methods for "Green IT maturity determination". Many companies (21\%) did not even know about this issue. This can be noted analogously in terms of "Green IT certification". Here, currently the "TÜV" dominates the "Green IT certification market".

Conclusion: Sustainability and Green IT are important issues for IT controlling and thus also for business and information systems engineering.

\section{References}

Deutsche Bank Research (2011) (ed) Green IT, more than a passing fad! Deutsche Bank, Frankfurt. http://www.dbresearch.com. Accessed 2011-01-13

Gadatsch A，Juszczak J (2011) Ergebnisse der Kurzumfrage zum Stand von Green IT im deutschsprachigen Raum 2011. In: Schriftenreihe des Fachbereiches Wirtschaftswissenschaft Sankt Augustin, vol 30. Hochschule Bonn-Rhein-Sieg, Sankt Augustin

Gadatsch A, Juszczak J (2009) Ergebnisse der Kurzumfrage zum Stand von Green IT im deutschsprachigen Raum (Green IT 2009). In: Schriftenreihe des Fachbereiches Wirtschaftswissenschaft Sankt Augustin, vol 24. Hochschule Bonn-Rhein-Sieg, Sankt Augustin

Loos P, Nebel W, Marx Gomez J, Hasan H, Watson RT, vom Brocke J, Seidel S, Recker J (2011) Green IT: a matter of business and information systems engineering? BISE $3(4): 245-252$ 